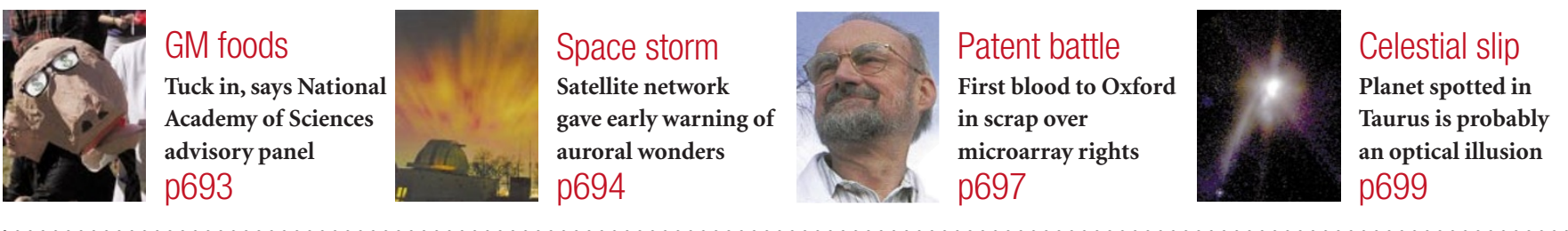

\title{
Critics challenge Celera's claims over human genome sequence...
}

\section{Washington}

Celera Genomics last week reached a significant milestone in the race to sequence the human genome. At a US House of Representatives subcommittee hearing, the company announced that it has completed the raw sequencing stage of its project.

But experts from the rival publicly funded Human Genome Project (HGP) believe Celera may have stopped short of its original goal. They question the company's claims that it will assemble the human genome within six weeks, and raise doubts over whether Celera, by itself, will be able to annotate the sequence by the end of the year.

The controversy over Celera's latest claim centres on the 'shifting finish line' in the raw sequencing race. When the company first announced that it would take on the human genome in 1998, it said it would single-handedly sequence the genome 10 times over (10X coverage) - the repeats being necessary for higher accuracy. Celera revised this goal to $4 \mathrm{X}$ sequence coverage in January this year (see Nature 403, 119; 2000), saying that it would then combine its proprietary data with the HGP's public data.

But, according to sequencing experts such as Philip Green from the University of Washington in Seattle, the 'endpoint' that Celera announced last week seems closer to 3.3X coverage.

The company claims to have achieved $11 \mathrm{X}$ 'clone coverage', a measurement that is notably different from sequence coverage. In each unit of sequence coverage, machines read the entire length of every DNA fragment. But in clone coverage, sequencers only scan the ends of each fragment, skipping over the middle.

Clone coverage lends itself to Celera's strategy for genome sequencing. The company uses a 'whole-genome shotgun' approach, in which it blasts a complete piece of DNA into millions of fragments of varying sizes, reads only their ends, then uses computer algorithms to match up the overlaps.

According to the company, the paired clone ends allow the genome to be assembled "much more completely than single-stranded sequencing methods allow at comparable

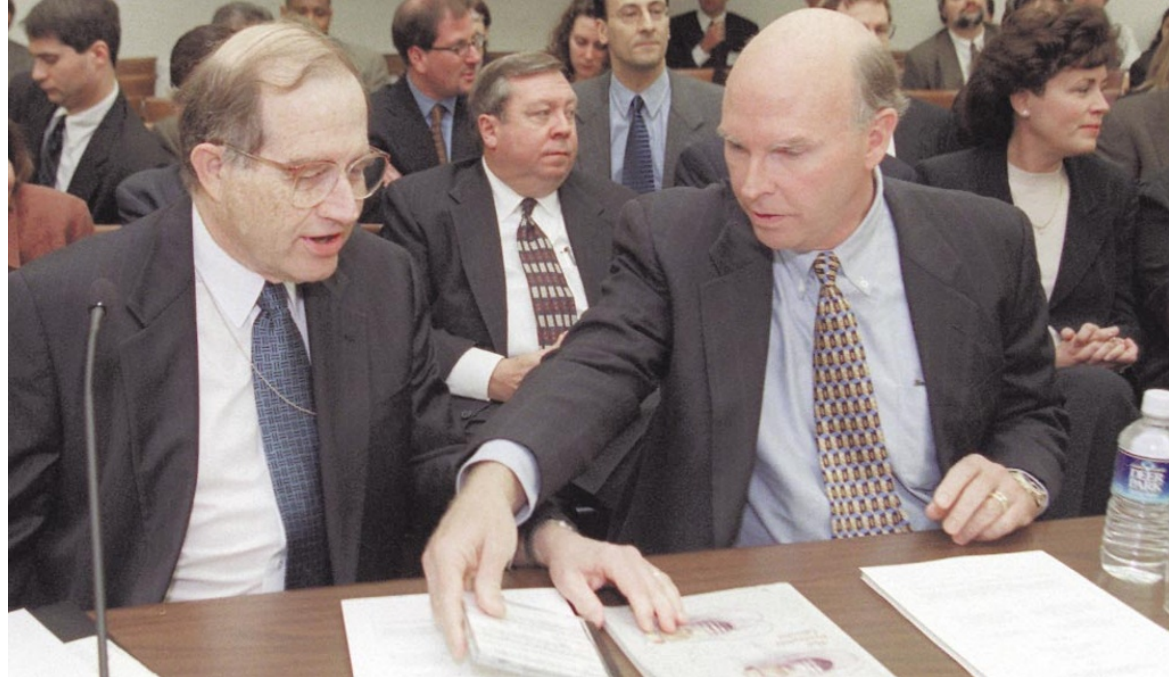

All join hands? US science adviser Neil Lane (left) and Celera Genomics head Craig Venter agreed last week that public/private collaboration would be desirable in principle.

levels of sequence coverage". But critics such as Green argue that Celera needs a higher amount of clone coverage to achieve the level of sequence coverage that ensures completeness and accuracy.

The public project, by comparison, is doing 'clone-by-clone' sequencing, reading each DNA fragment in its entirety, then placing it on a physical map.

The HGP's map serves as a scaffold on which both the public and the private projects can affix data. Robert Waterston, head of the

\section{....as biotech debate splits along party lines}

\section{Washington}

Last week's hearing on genomics, organized by the science, energy, and environment subcomittee of the US House of Representatives science committee (see above), was intended to educate committee members about progress in the field. But it ended up by politicizing the issue.

The hearing opened with a Republican denunciation of President Bill Clinton's recent remarks on gene patenting, whereas Democrats supported his remarks. It closed with a show of Republican support for the biotechnology industry in general, and Celera Genomics in particular. James Sensenbrenner,

(Republican, Wisconsin), chair of the House Committee on Science, blasted Clinton for making remarks about access to raw sequence data. Clinton's comments upset the biotech stock market last month, as some initially interpreted them as an attack on gene patentability.

Sensenbrenner said public officials should be careful about issuing such statements. "These events highlight the need for increased sensitivity on the part of government officials to the wellbeing of the high-tech sector," he said. But Jerry Costello (Democrat, Illinois) applauded the policy.

In closing, Ken Calvert (Republican, California) said that government's role is to initiate research on which private sector companies can capitalize, pointing to Celera Genomics as a prime example. He endorsed the way that Celera is incorporating the public Human Genome Project's data into its own database, adding its own sequence information, providing annotation tools, then selling it. 
- department of genetics at Washington University in St Louis, told the committee that because Celera has access to that scaffold - as well as to the public project's data - it will always be ahead in the gene mapping effort.

Waterston believes that Celera's level of coverage, when assembled, will result in over 40,000 gaps. He based his estimate on Celera's sequence of the fruitfly Drosophila, which, at a fraction of the size of the human genome, contained about 1,200 gaps. Green says the number of gaps in Celera's human sequence might be higher, as the company did not sequence the genome as many times over as it did the Drosophilagenome.

Nevertheless, Waterston, Celera's president Craig Venter and Neil Lane, President

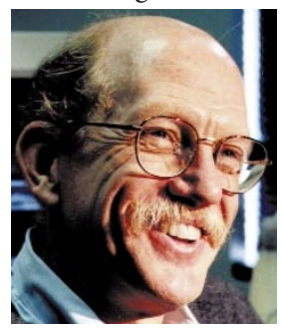

Bill Clinton's science adviser, all said at the subcommittee hearing that a formal collaboration would result in a better quality genome than either group could produce on its own. Indeed, each side may 40,000 sequence gaps. have something the other desires.

Although Celera has access to the public data, it has no guarantee that publicly funded scientists will volunteer to help annotate the human genome and fill in any gaps that remain once the two data sets are merged.

Public scientists participated in an 'annotation jamboree' for sequencing the genome of Drosophila. But that was on the understanding that the fruits of their labour would be available in GenBank, the publicly funded database. Celera has said it will make its version of the human genome available publicly, but only in its own database, and with restrictions on the use and redistribution of sequence data (see Nature 404, 324; 2000).

The public project, in turn, could use Celera's data to move up the completion date of its own project. The HGP has planned for a 'rough draft' of the genome with $5 \mathrm{X}$ sequence coverage by the end of this year, and a complete copy with 10X coverage in 2003.

Celera also plans to release its draft of the human genome by the end of this year - but only after it is fully assembled. By contrast, scientists can see new data being added to GenBank by the public project every 24 hours. This discrepancy between the two approaches has blocked formal cooperation from the beginning.

Celera's insistence that scientists should not be able to download, add to or redistribute information from either its prospective free or current public databases has placed further obstacles in the way of collaboration. Resolving them would allow for a more comprehensive human genome database sooner than either the public or private projects initially anticipated.

Paul Smaglik

\section{German parliament agrees on limits to bioethics inquiry}

\section{Munich}

The German parliament last week ended 18 months of controversy by deciding to set up an all-parliamentary commission d'enquête (commission of inquiry) on the ethical and legal aspects of biomedicine.

Opponents of such a commission had included Wolf-Michael Catenhusen, the biotechnology-friendly Social Democrat (SPD) secretary of research. He had feared that it would lead to cumbersome discussions of first principles that might delay legislation to bring the regulation of German biomedicine into line with the rest of Europe (see Nature 402, 331-332; 1999).

But the Greens - together with much of the media and the German public — had accused opponents of the commission of attempting to curtail political discussion about the ethical and social implications of biomedical and biotechnological progress.

Last week's compromise follows a reduction and streamlining of the inquiry panel's tasks. For example, the question of whether Germany should ratify the Council of Europe's Convention on Human Rights, which sets minimum ethical standards for European countries - but which Germany opposed because some clauses conflict with Germany's more restrictive national rules has been removed from the agenda.

Catenhusen welcomes the compromise. "I am optimistic that the commission will focus on really important issues, such as therapeutic cloning, now that we have turned away from setting up a combat group committed to fighting the Council of Europe Convention," he says.

The commission's purpose is now described as being to "work out recommendations for ethical assessment ... and for legislative and administrative action related to future medical opportunities". It will identify areas in which recent scientific developments have exposed a lack of appropriate legal rules, for example in stem-cell research or genetic testing.

Monika Knoche, the Green party's expert on medical ethics, says that genetic screening and reproductive technologies head the party's agenda for the commission.

The panel is scheduled to begin work next month, when its members - including 13 members of parliament and an equal number of external experts - will be nominated. It is not expected to include those holding 'extreme' positions. According to Catenhusen, this will reduce the chances of conflict found in the initial proposal, which would have included members known for their unwillingness to compromise.

Commissions d'enquête provide policy advice and prepare the introduction or modification of legislation. They are thus required to deliver final reports well before the end of a legislative period - a demand that, in the past, not all of them have been able to meet. Quirin Schiermeier \& Ulrike Hellerer

\section{Ontario joins the genomics goldrush}

\section{Montreal}

Canada's richest province, Ontario, is seeking to become an international force in genomics research. The Ontario Research and Development Challenge Fund (ORDCF) last week announced the approval of Can $\$ 74.2$ million (US\$51 million) for genomics-related projects. This sum will draw an additional Can\$134.7 million from research institutes and the private sector.

Ontario's plan predates the federal scheme to establish 'Genome Canada', comprising five national genome centres (see Nature 404, 8; 2000).

Last week's announcement of Ontario's projects was made by Jim Wilson, the province's energy, science and technology minister. Martin Godbout, named president of the national centre last month, has met with fund officials to discuss possible collaboration with Ontario's programme.
The projects approved for Ontario include a Centre for Genomic Computation, providing access to DNA sequences and analysis via the Internet. This will be housed at Toronto's Hospital for Sick Children, where new supercomputers have assumed management of the Genome Database of the international Human Genome Project. The database was transferred last year from Johns Hopkins University, Baltimore.

The Ontario Cancer Institute will host a proteomics facility, for producing pure proteins as drug targets, and a DNA microarray facility, for analysing information on the genetics of disease.

Each facility will serve the province as a whole. Seven more genomics proposals have been conditionally approved. Responses from the institutions involved, indicating whether all conditions have been met, are expected by the end of July. David Spurgeon 